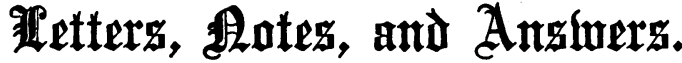

ORIGINAL ARTICLES and LETTERS forwa; ded for miblication are understood to be offered to the BRITISH MEDICAL JOURNAL alone unless the contrary be stated.

ADTHons desiring reprints of their articles published in the British MEDICAL JOURNAL are requested to

MaNUSCRIPTs Forwarded to the OFFICE of this Jotrnal caNiot UNDER ANY CirCUMSTANCES BE RETURNED.

Conrespondents who wish notico to be taken of their communications should authenticate them with their names of course not necessarily for publication.

Correspondents not answered are requested to look at the Notices to Correspondents of the following week.

Commonications respecting Editorial matters should be addressed to the Editrr. 429. Strand, London, W.C.; those concerning business be addressed to the Office, 429, Strand, London, W.C.

TELEGRAPHIC ADDREss. - The telegraphic address of the EDITOR of the BRITISH MEDICAL Journal is Aitiol cgy, London. 'T he telegraphic address of the BRITISH MEDICAI JOCRNAL is Articulate, London.

\section{TELEPHONE (National):-}

2631, G errard, EDITOR, BRITISH MEDICAL JOURNAL 2630, Gerrard, BRITISH MEDICAL ASSOCIATION.
2634, Gerrard, MEDICAL SECRETARY.

LT Queries, answers, and communications relating to subjects to which special departments of the BRITISH MEDICAL JOURNAL are devoted will be found under their respective headings.

\section{QUERIES.}

Mr. Frank KFnnedy Cahill, F.R.C.S. (Dublin), would like to find out whether there is a book in French corresponding to Deutsch's medical German, containing a list of medical terms in French, followed by conversations in the form of question and answer for each region of the body.

We know of none. Perhaps some of our readers may be able to supply the information required.

H. W. asks for information in the case of a young man, with no history of bladder, kidney, or urethral disease, who suffers when at home from frequency of micturition, the bladerer requiring to be emptied about every two hours. There is also rnarked urgency. On the other hand, he never requires to rise at night, and when on a visit from home, or when his rise at night, and when on a visit from home, or when his daily routine of work is interfered with, so that his mind is off his bladder, he can carry his urine for a normal time. the urine. 'The condition is of about two years' standing.

Mr. Bowles, SuRgeon, OF High Wyconbe.

S. D. C. writes: Dr. Martin Llewellyn of High Wycombe is said to have accompanied Charles I to the scaffold and to have received from the King the gloves he wore upon that occasion. The doctor is said to have transmitted these gloves to a great granddaughter, who married a Mr. Bowles, surgeon, of High Wycombe. Is anything known of this Mr. Bowles or of the present whereabouts of the gloves? The gloves recently obtained by a law suit have no documentary history, so I was informed by the gentleman who received them and who courteously gave me all the information hecould about them.

\section{INCOME TAX.}

TAXED has professional earnings of $£ 40$, and untaxel income from interest amounting to £8. The proportion of his rent regardable as paid for professional purposes is $£ 60$. On inquiring whether he is bound to pay income tax on the $£ 8$, he is referred to various sections of the Income Tax Acts.

** Our correspondent has two means of obtaining relief. He may, if his total income from all sources be under $£ 160$ or under $£ 700$, claim total exemption or an abatement, as the case may be; or, if his income exceed $£ 700$, he may prove that he has made a loss on his profession after charging all expenses, and may claim to be relieved of $\operatorname{tax}$ on other income to the extent of that loss, under the Customs and Inland Revenue Act, 1890. He should communicate with the Surveyor of Taxes accordingly.

F. D. H. R. receives a salary of $£ 150$ and extra fees as district medical officer, and wishes to know whether he may return his salary for assessment under Schedule $E$ and the extra fees under Schedule $D$, together with his income from private practice.

$*_{* *}^{*}$ The Revenue authorities will raise no objection to the inclusion in the general return under Schedule $\mathrm{D}$ of both the salary and the fees on the average of the three preceding rears; they might, perhaps, demur to treating the salary under Schedule $E$ and the fees under Schedule $D$. though there is much to be said for that course.
LETTERS, NOTES, ETC.

Dr. A. A. WARden (Paris) writes: It is impossible to rear without the greatest interest all that Mr. Leonard Hill write on his experiences with oxygen as a therapeutic agent. One gathers that the usual methed by which Mr. Hill has administered oxygen is by inhalation, the defects and uncertainty of which have led him to construct the ingenious apparatus figured on p. 71 of the BRITISH MEDICAL JOURNAL, January 13th. Mr. Hill states that "undue alarm as to the
poisonous effect of oxygen has been felt by the medical poisonous effect of oxygen has been felt by the medical profession," but our neglect has surely rather been due to our ignorance of its physiological action and therapeutic value, has been at our disposal for applying it. Mr. Hill points out has been at our disposal for applying it. Mr. Hill points out that " in the struggle with the invading micro-organism (in pneumonia) oxygen helps to maintain the strength of the heart and so preserve the patient until the process of immuniza-
tion is established and the disease arrested," the object tion is established and the disease arrested," the object
evidently being to get the oxygen absorbed as quickly as possible. Surely then the subcutaneous injection of oxycen has many advantages over its inhalation, not only in diseases of the respiratory tract, but also in many other conditionsseptic infections, tuberculosis, anaemia, etc. For many years Professor Thiriar, of Brussels, and others have thus used oxygen. In 1906 Dr. Albert Rouet published a case of ascitic tuberculous peritonitis successfully treated by the intraperitoneal injection of oxven. In December 1910 injected several litres of oxygen in a patient with bed 1910 , injected several litres of oxygen in a patient with bad double pneumonia, The great difficulty hitherto has been that of injected, the only apparatus available being the large metallic injected, the only apparatus available being the large matallic
reservoirs used in commerce, or the oxygen bag. (I used Professor Thiriar's instrument filled from a large cylinder Professor Thiriar's instrument filled from a large cylinder
under pressure.) This difficulty has now been overcome by under pressure.) This difficulty has now been overcome by the admirable apparatus designed by my friend, Dr. Raoui, Bayeux, and presented by him at the Academy of Sciences on
November 20th, 1911. It consists of three parts: (1) A light November 20th, 1911. It consists of three parts: (1) A light (2) A series of small cylinders containing the oxygen under a pressure of 100 atmospheres, so that a litre of the gas is about the volume of a cigar. (3) A sensitive tap that allows the oxygen to be distributed at rates varying from $1 \mathrm{c.cm}$. to 1 litre per mirute. I believe that in oxvgen thus used we have a non-toxic and potent remedy likely to prove of use in many pathological conditions.

\section{A Study of " Psychical Reseatch.'}

In the review of Dr. Tuckett's book, The Evidence for the Supernatural, which appeared in the Journal of February 10th, at line four from the bottom of the first column of $p .309$, the title of the work by Mr. Whetham, F.R.S., referred to as "Recent Development of Psychical Research "is the ficent Development of 1 'hysieal Soience.

\section{SHADOW TEST IN RETINOSCOPY.}

DR. GEORGE HARDYMdN (Bath) writes: In calculating the spinerical and cylind aical dioptric measurement by the shadow test in retinoscops, I have found the following algebraic formula useful :

$$
\frac{x-1}{+(y-x) \phi}
$$

$x$ being the dioptric measure of the lensabolishing the shadow in the horizontal meridian, and $y$ the dioptric measure of the lens abolishing the shadow in the vertical meridinn.'. The calculation is mado as if the axis was vertical, and aftel:wards corrected if it be not so. The above formula, I believe, holds good for all forms of rcgular astigmatism as well as for emmetropia, hypermetropia, and miopia.

$$
\text { ERRATA. }
$$

THF following corrections should be made in Dr. Crofton's address on the prevention and treatment of pulmonary tuberculosis, published in the JovkNat for February 10th :

Page 295, col. 1, lines 36-38, for " 13 (8 per cent.), in the case of males and of 15 ( 6 per cent.) in the case of females," read " 13 to 8 per cent. in the case of males, and of 15 to 6 per cent. in the case of females."

Page 296, col. 1, line 50, for "neurones," read "hormones.'

Page 298, col. 2, line 26, for " cases," read " causes."

Page 298, col. 2, lines 35-36, for " acts as an excellent stimulant and for the formation of antitoxin," read "acts as an excellent stimulant for the formation of antitoxin."

BCALE OF CHARGES FOR ADY ERTIBEMENTS IN THE BRITISH MEDICAL JOURNAL.

Eight lines and under

Each additional line

A whold

$$
\begin{array}{cccccccc} 
& & & & \delta & 8 . & d . \\
\ldots & \ldots & \ldots & \ldots & 4 & 0 \\
\ldots & \ldots & \ldots & \ldots & 0 & 0 & 6 \\
\ldots & \ldots & \ldots & \ldots & 2 & 13 & 4 \\
& \ldots & \ldots & & \ldots & 0 & 0
\end{array}
$$

Än average line contains six $\ldots$ words.

All remittances by Post Office Orders must be made payable to the British NIedical Association at the General Post Office, London. safeguarded.

Advertisements should be delivered, addressed to the Manager. 429, Strand, London, not later than the first post on Wednesday morning
preceding publication, and, if not paid for at the time, should be
accompanied by a reference. Nompanied by a reference.

Nort.- It is against the rules of the Post Office to recelve nostes 